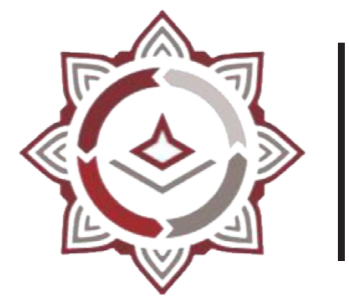

BISNIS: Jurnal Bisnis dan Manajemen Islam

P-ISSN: 2442-3718, E-ISSN: 2477-5533

Volume 9, Nomor 2, Desember 2021 (PP : 205-224)

https://journal.iainkudus.ac.id/index.php/Bisnis/index

http://dx.doi.org/10.21043/bisnis.v9i2.11999

\title{
Can Religious Tourism Meet Tourist Satisfaction through its Halal-Friendly?
}

\author{
Saifudin \\ IAIN Salatiga \\ saifudin@iainsalatiga.ac.id
}

\begin{abstract}
Religious tourism has been widely discussed in the tourism business literature, but exploratory studies on religious tourism are not enough, especially in the field of halal-friendly tourism. This study aims to determine the effect of halal-friendly on tourist satisfaction on religious tourism. Halal-friendly is limited to halal-friendly accommodation, halal food, halal-friendly facilities, halal-friendly service, and the friendliness of local residents. A total of 534 respondents were selected using purposive sampling method and analyzed using SmartPLS 3.2.9. The results of the study explain that halal-friendly accommodation, halalfriendly facilities, and the friendliness of local residents and other tourists affect tourist satisfaction. However, halal food and halal-friendly service do not affect tourist satisfaction.
\end{abstract}

Keywords: Halal-Friendly, Satisfaction, Accommodation, Food, Facilities, Service, Local Residents

\section{INTRODUCTION}

Religious tourism has become a recurring phenomenon in the history of religion and refers to forms of tourism that have religious associations. Before religious tourism developed today, some managerial suggestions to maintain the sanctity of sacred places were to keep the destination away from commercialization, limit some areas from visitors, introduce religious knowledge through unique guides and control overcrowding (Hung et al., 2017:2). Although religious tourism destinations must be kept sacred, they still provide their attraction for tourists.

Over time, relevant religious tourism studies have investigated topics in diverse destinations, such as worship sites, religious tourism attractions, pilgrimage routes, 
and festivals (Kim et al., 2020:1). Previous studies have highlighted the different topics of religious tourism within the broader tourism phenomenon, especially in terms of the connotations of pilgrimage the transition of pilgrimage to tourism from a tourism perspective. Today, topics in the general category of religious tourism and pilgrimage have developed into secularity considerations (Hung et al., 2017:3).

In Indonesia, religious tourism for the Muslim community generally is a pilgrimage to the guardian's grave known as the wali songo and wali limo pilgrimages (Handriana et al., 2020:785). One of the Wali Songo pilgrimages known in Central Java is Demak, which the government brands as the city wali. As an Islamic tourist destination, Demak should implement halal-friendly for its visitors.

Previous studies in tourism emphasized the importance of halal-friendly for Muslim tourists and how it affects their satisfaction during their trip (Al-Ansi \& Han, 2019). Although Demak is visited by local and foreign Muslim tourists every year, the fact is that until now, Demak has not been eyed by the central government as a halal tourism destination (Kemenparekraf RI, 2021), so it is necessary to make development efforts, including research on halal tourism in Demak. Especially amid the uncertainty of the COVID-19 pandemic (Kasdi \& Saifudin, 2020:82), it is essential to conduct an in-depth study along with the decline in tourists travelling to Demak (BPS-Statistic of Demak, 2021).

Several previous researchers have researched halal-friendly, such as research by Saputro et al. (2018:278), which proves halal-friendly facilities at a destination can shape tourist satisfaction. Research by Jeaheng et al. (2020:18) stated that halalfriendly accommodations shape the fulfilment of Muslim tourists. But in contrast to the results of other studies, which say that halal-friendly in the Islamic service sector and halal food shows an insignificant effect on tourist satisfaction, this is demonstrated by the research of Kasdi \& Saifudin (2019:127) and Atieq (2020:119). So that more in-depth research is needed on the application of halal-friendly in tourist attractions. This research is interesting because it differs from previous research, which separates halal tourism from religious tourism. This study reveals how far halal-friendly is applied in religious tourism destinations. 


\section{LITERATURE REVIEW}

\section{Islamic Consumer Behaviour}

Consumer behaviour involves the use and disposal of products and services and how these products and services are purchased (Mohammadi \& Mohamed, 2011:151). Products or services often used by consumers are beautiful to marketers because this can help them find out how a product or service is positioned well to encourage consumers to increase their consumption. The consumer behaviour model has a straightforward goal: a systematic and in-depth understanding of the buying process (Mohammadi \& Mohamed, 2011:151).

In response to the above, Islamic consumer theory becomes essential. An Islamic consumer theory views eternal happiness as the goal of life for an individual. One action is strongly influenced by virtue considerations rather than maximizing oneself for action without limitations (Amin et al., 2014:274). The motive of Muslim consumer theory is to predict a person's behaviour within Islamic norms. It encourages one's actions based on need because of Allah SWT because halal consumption in sharia rules is considered a virtue in Islam.

\section{Tourist Satisfaction}

Satisfaction is a condition where the desires, expectations and needs of customers are met. Customer satisfaction is an evaluation where the chosen alternative is equal to or exceeds customer expectations, while dissatisfaction arises when the results cannot meet customer expectations (Agusmal \& Wardi, 2020:593).

Tourist satisfaction can be interpreted as feeling happy or disappointed by a visitor due to comparing the performance of a product or service with his expectations. Tourist satisfaction can also be understood as a tourist's perception of the performance of goods and services concerning his expectations. If the version offered does not match their expectations, tourists will feel dissatisfied (Alam et al., 2019:59). The tourist satisfaction indicators in this study adopted the satisfaction instrument used by Al-Ansi et al. (2019:5), namely: satisfied with my travel experience, visit Demak trip was a wise one, and I enjoy travelling. 


\section{Halal-Friendly}

As religious awareness increases and the tourism industry demands greater demands, halal-friendly practices can become a competitive strategy for the tourism industry in Muslim-majority countries. Halal-friendly exercises will also help increase the overall level of customer satisfaction in the hotel industry in Muslim-majority countries (Mahrnasari et al., 2020:191). However, this will also improve management costs which can be one of the main challenges for implementing halal-friendly practices in tourism. For example, for the satisfaction of Muslim customers, a destination might provide prayer equipment, which adds to the cost of the traditional management policy of no prayer equipment.

\section{a. Halal-Friendly Accommodations}

Tourism infrastructure will not be fulfilled without accommodation considerations, so accommodation plays a vital role in tourism development. Capacity is responsible for creating a tourist feeling like being at home ((Baniya \& Thapa, 2017:47). Halal-friendly hotels have an essential role in influencing consumer choices, especially in determining their accommodation plans. Hotels with superior attributes can better win the competition by controlling all critical aspects consumers consider in choosing hotels (Baniya \& Thapa, 2017:48).

The indicators of halal-friendly accommodation in this study adopt the instrument used by Han et al. (2019:1018), which consists of the hotel provides products/services that follow Islamic law, provides a hand shower bidet in the toilet, interior decoration of the hotel is free of paintings containing nudity, and design offers privacy and confidentiality. Jeaheng et al. (2020:18) have also proven that halal-friendly accommodations are proven to affect visitor satisfaction, so from this explanation, a hypothesis can be drawn:

H1: Halal-friendly accommodations have a positive effect on tourist satisfaction 


\section{b. Halal Foods}

Halal food and beverage is a crucial sector in the halal tourism industry. The halal food and beverage sector is different and attracts many investors and entrepreneurs worldwide (Ali, 2018). Muslims in non-Muslim countries demand halal food products and growing awareness of the potential global halal food market. It could also be because consumers are increasingly aware that halal food products are potentially healthier, safer, hygienic, and produced using clean facilities, making them more popular (Purwanto et al., 2020:16). In addition, consumers buy food labelled as halal because it is considered a healthy food product and because they are concerned about food safety. The concept of halal food represents the cleanliness, purity and quality of the food consumed (Purwanto et al., 2020:16). Halal foods are proven to affect tourist satisfaction (Putit et al., 2016:45).

The halal foods indicator in this study adopted the instrument used by Han et al. (2019:1018), which consisted of availability of halal food at tourist spots, halal food and drink offered according to Islamic law, halal food restaurant displays the halal logo. Halal food and drinks at tourist sites are clean, safe, and hygienic. From the explanation above, a hypothesis can be drawn:

H2: Halal foods have a positive effect on tourist satisfaction

\section{c. Halal-Friendly Facilities}

Muslim travellers often think about sharia rules (Islamic principles) to guide their preferences for tourist spots and locations when choosing a travel destination. For tourist attractions with Muslim visitors, it must be adjusted to specific attributes provided by the travel provider (Mahrnasari et al., 2020:193). Items that are important for Muslim tourists such as the provision of prayer facilities. It can further be expanded to provide information on places of worship (mosques) for prayer.

The halal-friendly facilities indicator in this study modifies the instrument used by Jeaheng et al. (2020:24), consisting of mosques, separate mosque facilities for men and women, and halal facilities in tourist 
attractions that are clean, safe, and hygienic. Halal-friendly facilities will increase the satisfaction of visiting tourists (Saputro et al., 2018:278). From the explanation above, a hypothesis can be drawn:

H3: Halal-friendly facilities have a positive effect on tourist satisfaction

\section{d. Halal-Friendly Services}

Service performance in the tourism industry influences tourists' perceptions of quality based on how services are prepared and delivered. This idea describes the sensitivity of service quality and its role in customer decision-making (Jeaheng et al., 2020:3). Visitors will evaluate the service quality of the tour provider based on their expectations and the performance of the services provided.

The indicators for halal-friendly services in this study modify the instrument used by Jeaheng et al. (2020:24), which consists of service providers are very understanding of Islamic rules, halal services according to Islamic law, male/female staff wear uniforms that comply with sharia law, and when staff meet Muslim tourists say salam. Jeaheng et al. (2020:5) emphasize a significant relationship between halal service performance and customer satisfaction so that it requires consistent improvement to meet customer needs so that a hypothesis can be drawn:

H4: Halal-friendly services have a positive effect on tourist satisfaction

\section{e. Halal-Friendly Locals and other Travelers}

Although not widely studied in the tourism literature today, one's comfort experience while travelling to a particular destination is significant in explaining the formation of his tourism decisions and behaviour. One of them is the convenience of tourists when interacting with residents around tourist destinations. The friendliness of local people and local tourists encourages someone to visit a destination Corte et al., (2015:45) (Han et al., 2019:1014).

The indicators for halal-friendly locals and other travellers in this study adopted the instrument used by Han et al. (2019:1018), which 
consisted of feeling welcomed by local people, local people and other tourists generally have a positive attitude towards tourists, and local people and other tourists are kind and helpful to tourists. From the explanation above, it can be assumed to be a hypothesis:

H5: Halal-friendly locals and other travellers have a positive effect on tourist satisfaction

\section{RESEARCH METHODS}

This study uses a quantitative approach, which detects the relationship between two or more variables. The relationship in this study is a causal relationship, where there are exogenous variables that affect endogenous variables.

The population in this study is the number of visitors to the religious tourism in Demak whose exact number is not known, so that the sample collection method using convenience sampling is used, namely the sample collection method by taking samples that are strategically located around the research location (Edgar \& Manz, 2017:106).

The number of samples taken in this study was 534 people taken by simple random and incidental sampling. The data used are primary data obtained directly from tourists using a questionnaire. The tool used in this research is path analysis to determine how much influence some exogenous variables have on endogenous variables.

This study uses data processing tools SmartPLS 3.2.9 software. PLS (Partial Least Square) is a variant-based structural equation model (PLS) analysis that can simultaneously test the measurement model and test the structural model. While the framework of this research is shown in figure 1 below: 
Figure 1

Conceptual Model

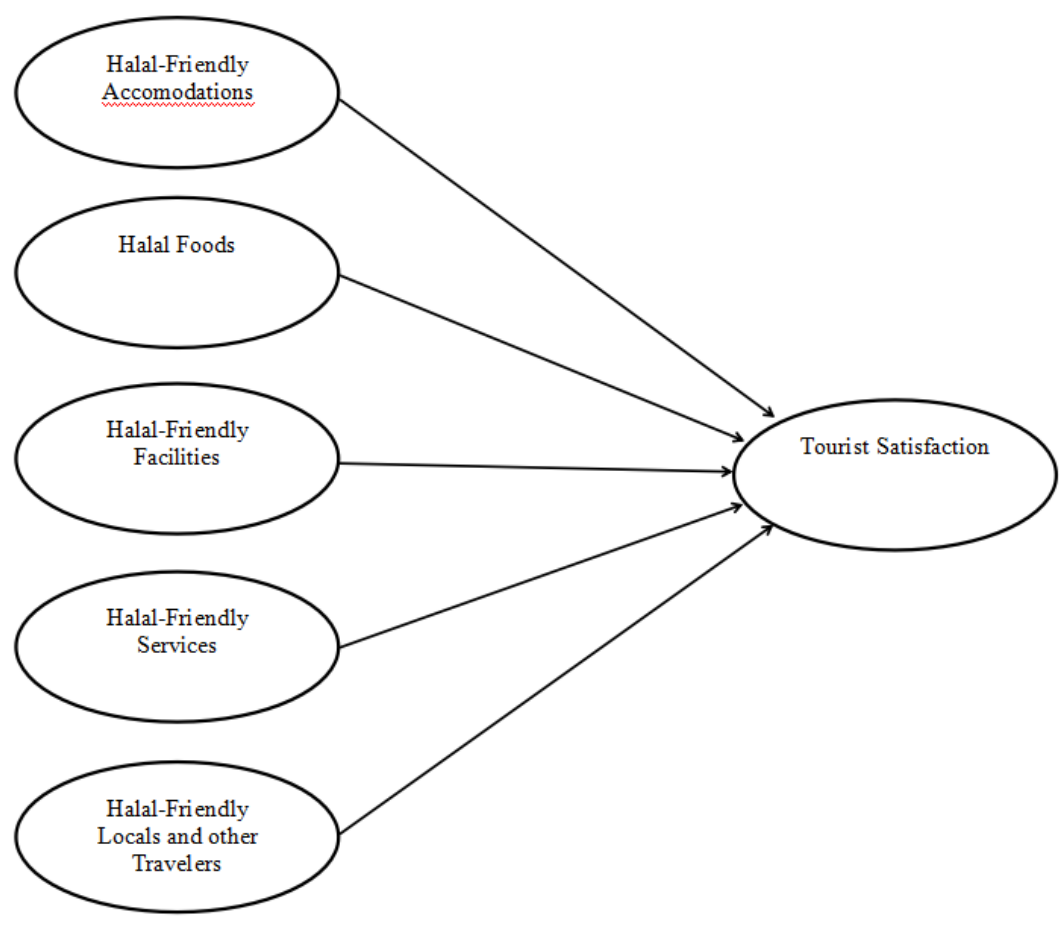

Source: Model developed 2021

\section{DISCUSSION}

1. Descriptive Statistical Analysis

Based on the results of the researchers' observations, the respondents' descriptions were obtained as follows:

Table 1.

\section{Demographic Information}

\begin{tabular}{lr}
\hline Demographic & Percentage \\
\hline Gender & \\
Male & 41.6 \\
Female & 58.4 \\
& \\
Age & \\
$21-25$ & 76.6 \\
$26-30$ & 7.5
\end{tabular}


$31-35$

$36-40 \quad 1.5$

$41-45 \quad 4.5$

46-50 4.7

More than 50 years 2.8

\section{Province}

$\begin{array}{ll}\text { Banten } & 0.4\end{array}$

$\begin{array}{ll}\text { Bengkulu } & 0.2\end{array}$

Special Region of Yogyakarta (DIY) $\quad 0.2$

DKI Jakarta $\quad 0.2$

West Java $\quad 2.2$

Central Java 94.6

East Java $\quad 1.3$

Riau 0.4

$\begin{array}{ll}\text { South Sumatra } & 0.6\end{array}$

\section{Profession}

$\begin{array}{ll}\text { Financial Services } & 0.9\end{array}$

Personal Services $\quad 1.3$

Tourism Service $\quad 0.6$

General Services $\quad 1.5$

Health $\quad 0.7$

Construction Field $\quad 0.7$

Manufacturing $\quad 4.5$

$\begin{array}{ll}\text { Social Work } & 0.9\end{array}$

$\begin{array}{ll}\text { Government } & 0.9\end{array}$

Field of education $\quad 7.1$

Trade Field $\quad 8.8$

Agriculture, Plantation, Livestock $\quad 4.1$

Telecommunications $\quad 0.4$

Student $\quad 50.9$

Other 16.5

Source: Data processed 2021

Based on the information in table 1 above, it can be seen that the respondents of religious tourism in Demak district are women, as many as $58.4 \%$, and the remaining $41.6 \%$ are men. Visitors are also mostly aged 21 25 years, as many as 76.6, the rest are spread in the age range of 26-50 years. When viewed from the origin of the respondents, most of them came from 
the province of Central Java as many as 94.6 and the rest were spread from the island of Java and outside Java. Visitors are also dominated by people with student work backgrounds, as much as $50.9 \%$, the rest are scattered with various professions in the table above.

\section{Analysis of Statistical Test Results}

a. Outer Model Analysis

To evaluate this research instrument, validity and reliability tests were carried out, and the test results can be seen in Table 2 below:

Table 2

Construct Validity and Reliability

\begin{tabular}{|c|c|c|c|c|c|}
\hline Construct and items & FL & $\mathrm{CA}$ & rho_A & CR & AVE \\
\hline Halal-Friendly Accommodations & & 0.736 & 0.745 & 0.804 & 0.578 \\
\hline $\begin{array}{l}\text { ACC1: The hotel provides halal-friendly } \\
\text { products/services that follow Islamic law }\end{array}$ & 0.790 & & & & \\
\hline $\begin{array}{l}\text { ACC2: Hotel rooms provide a hand } \\
\text { shower bidet in the toilet }\end{array}$ & 0.786 & & & & \\
\hline $\begin{array}{l}\text { ACC3: The interior decoration of the hotel } \\
\text { is free of paintings containing nudity }\end{array}$ & DO & & & & \\
\hline $\begin{array}{l}\text { ACC4: Hotel room design provides } \\
\text { privacy and confidentiality }\end{array}$ & 0.701 & & & & \\
\hline Halal Foods & & 0.730 & 0.734 & 0.832 & 0.554 \\
\hline $\begin{array}{l}\text { F001: Availability of halal food at tourist } \\
\text { spots }\end{array}$ & 0.783 & & & & \\
\hline $\begin{array}{l}\text { FO02: Halal food and drink offered } \\
\text { according to Islamic law }\end{array}$ & 0.681 & & & & \\
\hline $\begin{array}{l}\text { FOO3: Halal food restaurant displays } \\
\text { Halal logo }\end{array}$ & 0.796 & & & & \\
\hline $\begin{array}{l}\text { F004: Halal food and drinks at tourist } \\
\text { sites are clean, safe, and hygienic }\end{array}$ & 0.711 & & & & \\
\hline Halal-Friendly Facilities & & 0.732 & 0.737 & 0.832 & 0.553 \\
\hline FAC1: Availability of mosques & 0.709 & & & & \\
\hline $\begin{array}{l}\text { FAC2: Separate mosque facilities for men } \\
\text { and women }\end{array}$ & 0.766 & & & & \\
\hline FAC3: In general, mosque access is easier & 0.740 & & & & \\
\hline
\end{tabular}


FAC4: Halal facilities in tourist attractions are clean, safe, and hygienic

0.757

Halal-Friendly Services

0.764

0.786

0.864

0.680

SER1: Service providers are very

understanding of Islamic rules

0.888

SER2: Halal services according to Islamic

law

0.897

SER3: Female staff wear uniforms that

comply with sharia law

DO

SER4: Male staff wear uniforms that comply with sharia law

DO

SER5: When staff meet Muslim tourists say salam

DO

Halal-Friendly Locals and other Travelers

0.828

0.828

0.897

0.744

LOC1: I feel welcomed by local people when travelling to Demak

0.760

LOC2: Local people and other tourists

generally have a positive attitude towards

tourists

LOC3: In general, local people and other tourists are kind and helpful to tourists

\begin{tabular}{lccccc}
\hline Tourist Satisfaction & & 0.744 & 0.745 & 0.887 & 0.796 \\
\hline $\begin{array}{l}\text { SAT1: Overall, I am satisfied with my } \\
\text { travel experience in Demak as a halal- } \\
\text { friendly destination }\end{array}$ & 0.861 & & & & \\
$\begin{array}{l}\text { SAT2: My decision to visit Demak for a } \\
\text { halal-friendly trip was a wise one }\end{array}$ & 0.852 & & & & \\
$\begin{array}{l}\text { SAT3: Overall, I enjoy travelling to Demak } \\
\text { as a halal-friendly destination }\end{array}$ & 0.874 & & & \\
\hline
\end{tabular}

Source: Processed data 2021

Items with a loading factor value below 0.50 are excluded from the measurement model until a value above 0.50 is met so that the loading factor and AVE are achieved. The results showed that one item was excluded from halal-friendly accommodations. The hotel's interior decoration is free of nudity paintings due to its lower loading factor value below 0.50 . In addition, there are three items from halal-friendly services: female staff wear uniforms that comply with sharia law; male staff wear uniforms that comply with sharia law, and when staff meet Muslim tourists say salam because of the loading factor value of the three indicators is lower below 0.50 . 


\section{Figure 1}

\section{Measurement Model}

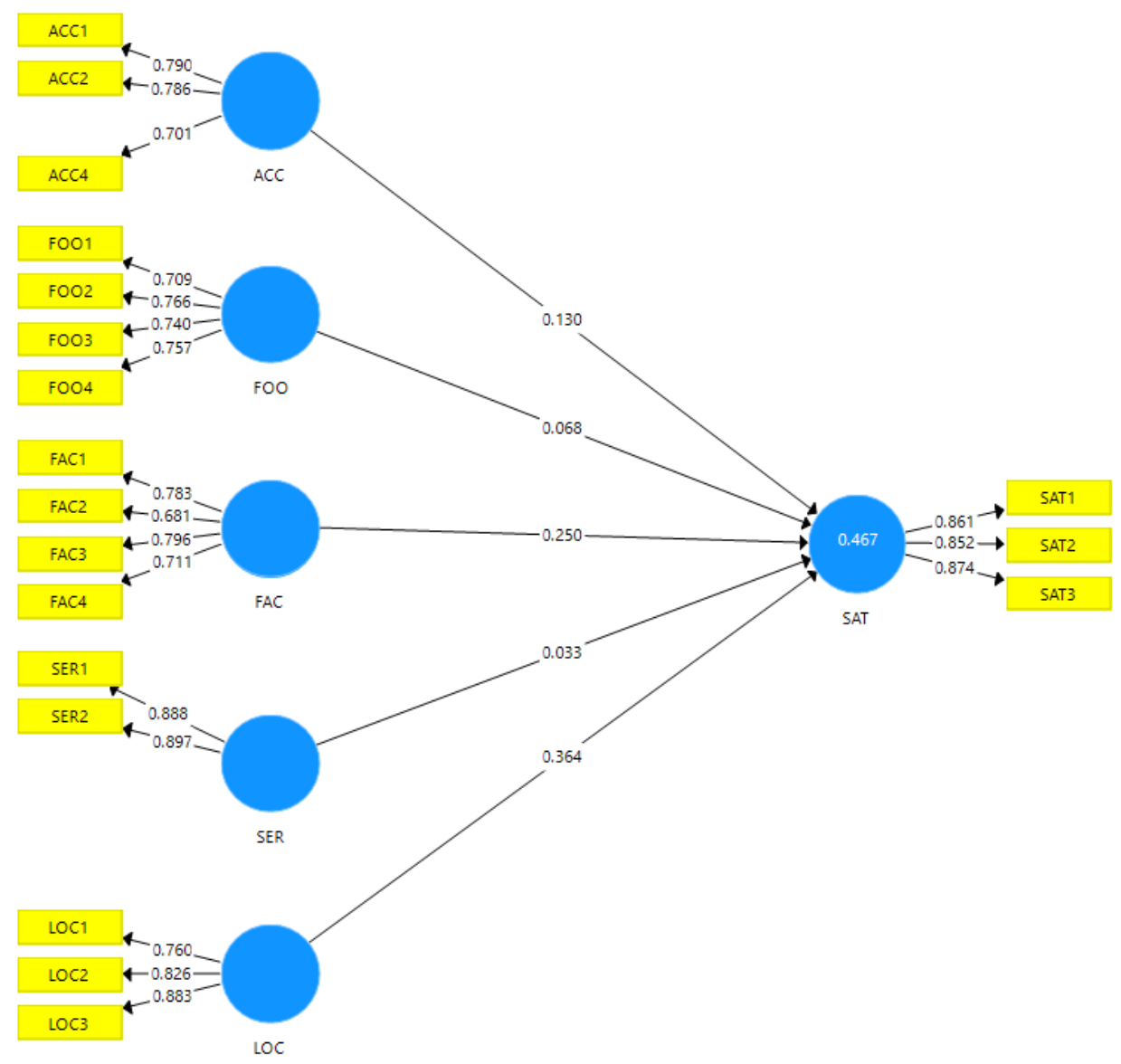

Source: Processed data 2021

After removing the four indicators in the study, it can be seen that the loading factor of each construct is above 0.50 and has reached the criteria of convergent validity (Sarstedt et al., 2014:108), as shown in Figure 1.

According to Dijkstra \& Henseler (2015:3), the cut-off value of the Rho_A coefficient should be greater than 0.70 as composite reliability, where the value in this study ranges from 0.730 to 0.828 so that it has achieved composite reliability.

Furthermore, suppose you look at table 2 above. In that case, it can be seen that the value of Cronbach's alpha is more significant than 0.60 , which 
reflects the reliability of all indicators in the model that are considered good. In addition, composite reliability greater than 0.70 also meets the standard. The AVE value is also greater than 0.50 , with the interpretation that one latent variable can explain more than half the variance of the manifest variable (indicator) on average (Ghozali, 2021).

Table 3

Discriminant validity

\begin{tabular}{lcccccc}
\hline \multicolumn{1}{c}{ Constructs } & ACC & FAC & FOO & LOC & SAT & SER \\
\hline Halal-Friendly Accomodations & 0.760 & & & & & \\
Halal Foods & 0.448 & 0.744 & & & & \\
Halal-Friendly Facilities & 0.538 & 0.624 & 0.744 & & & \\
Halal-Friendly Services & 0.370 & 0.545 & 0.532 & 0.824 & & \\
Halal-Friendly Locals and other & 0.428 & 0.567 & 0.506 & 0.603 & 0.862 & \\
Travelers & 0.463 & 0.542 & 0.574 & 0.564 & 0.473 & 0.892 \\
Tourist Satisfaction & & & & & & \\
\hline
\end{tabular}

Source: Processed data 2021

Furthermore, if you look at the value of the discriminant validity test, it can be explained that the construct in this study has reached the specified requirements. This is following the statement of Dijkstra \& Henseler (2015:4) that the square root of the AVE for each latent construct must be higher than the correlation of other latent constructs.

b. Inner Model Analysis

Evaluation of the inner model includes value analysis of R-Square, Q-Square, SRMR and NFI. A summary of the test results is shown in table 4 below:

Table 4

Inner Model Test Results

\begin{tabular}{ll}
\hline & Value \\
\hline R Square & 0.467 \\
R Square & 0.462 \\
Q $^{2}(=1-S S E / S S O)$ & 0.339 \\
SRMR & 0.071 \\
NFI & 0.722 \\
\hline
\end{tabular}

Source: Processed data 2021 
From the table above, it can be analyzed that the R-square (R2) value for tourist satisfaction is 0.467 . This means that the model is in the moderate category because it is below 0.67 . (Ghozali, 2021). Then from the table, it can be explained that the Q-square tourist satisfaction value of $0.339>0$ (zero) has an excellent predictive relevance value (Ghozali, 2021). Furthermore, the fit model test is based on the SRMR value, which should be below 0.08 , and the Normal Fit Index (NFI) value is $>0.90$ (Ghozali, 2021). From the above results, the SRMR value of 0.071 is considered eligible, but the NFI value of 0.722 is deemed marginal.

c. Hypothesis test

Hypothesis testing is to explain the direction of the relationship between the exogenous variables and the endogenous variables. Testing is done using path analysis of the model that has been made. The results for path coefficients analysis are shown in the image below:

Figure 2

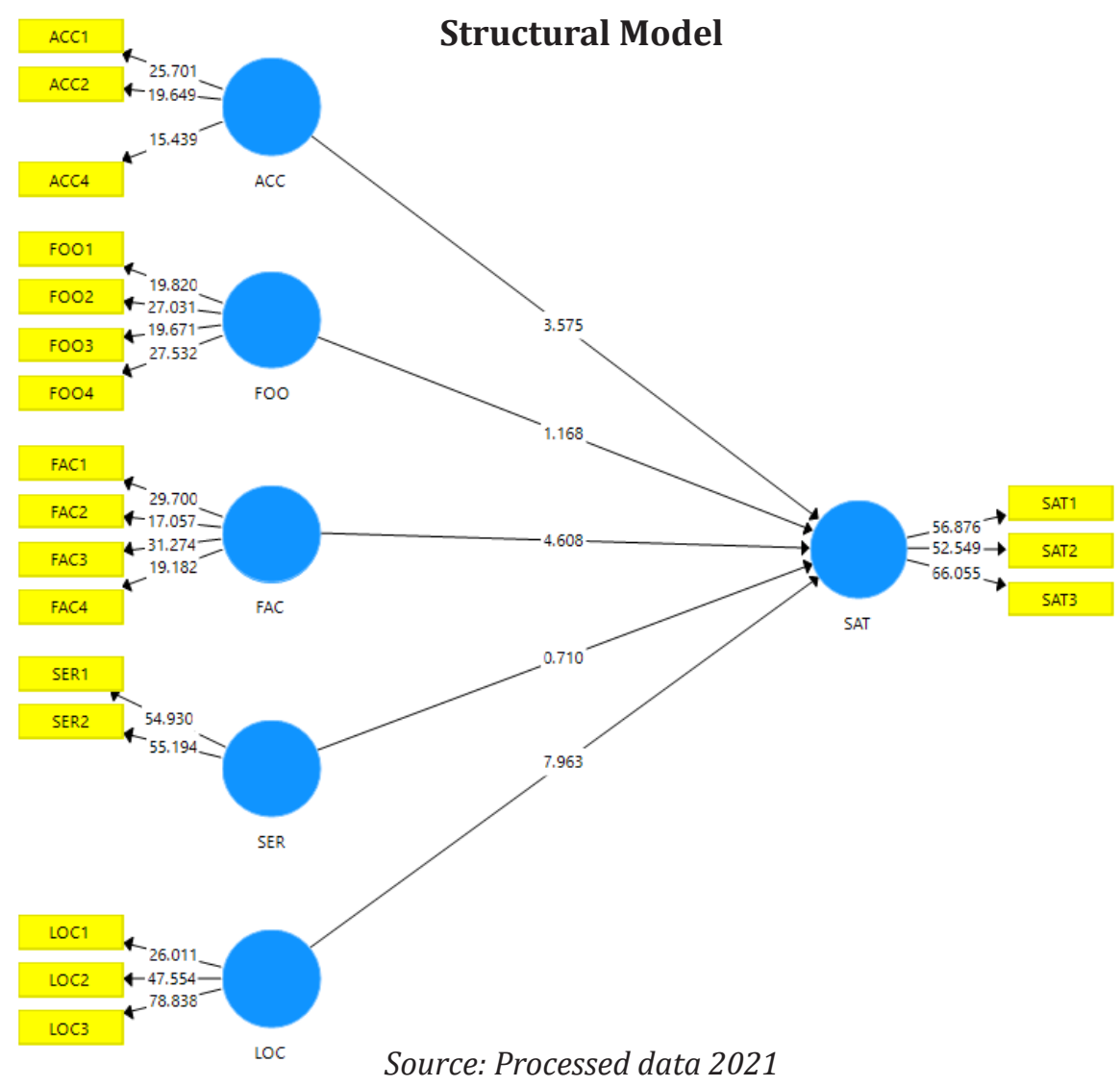


Based on Figure 2 above, it can be explained that the T Statistics value ACC -> SAT is 3,575, FAC -> SAT is 4,608, FOO -> SAT is 1,168, LOC -> SAT is 7,963 , and SER -> SAT is 0.710 which is greater than the value. t-table is 1.6477 .

Table 5

Path Coefficients

\begin{tabular}{lccccc}
\hline $\begin{array}{l}\text { Hypotheses } \\
\text { relationship }\end{array}$ & $\begin{array}{c}\text { Original } \\
\text { Sample (0) }\end{array}$ & $\begin{array}{c}\text { Standard Deviation } \\
\text { (STDEV) }\end{array}$ & $\begin{array}{c}\text { T Statistics } \\
(\mid \text { OOSTDEV|) }\end{array}$ & $\begin{array}{c}\mathrm{P} \\
\text { Values }\end{array}$ & Conclusions \\
\hline ACC -> SAT & 0.130 & 0.036 & 3.575 & 0.000 & Accepted \\
FOO -> SAT & 0.068 & 0.058 & 1.168 & 0.122 & Rejected \\
FAC -> SAT & 0.250 & 0.054 & 4.608 & 0.000 & Accepted \\
SER -> SAT & 0.033 & 0.046 & 0.710 & 0.239 & Rejected \\
LOC -> SAT & 0.364 & 0.046 & 7.963 & 0.000 & Accepted \\
\hline
\end{tabular}

Source: Processed data 2021

From table 5 above, it can be seen that the value of the original sample estimate ACC -> SAT is positive at 0.130 with a significance of 0.000 less than 0.05 , meaning that halal-friendly accommodations have a positive effect on tourist satisfaction. Likewise, halal-friendly facilities and halalfriendly locals and others are significant at 0.000. On the other hand, FOO -> SAT has a significance of 0.122 , and SER -> SAT has a value of 0.239 , both of which are more significant than 0.05 so that it can be interpreted as having no significant effect.

\section{Discussion}

Based on the results of the data analysis above, it can be seen that first, halal-friendly accommodations positively influence tourist satisfaction who travel to Demak. Tourists also appreciate the hotel for providing halal-friendly products and services that follow Islamic law; the results of this study support previous research conducted by Jeaheng et al. (2020:18). 
Second, it turns out that halal foods do not affect tourist satisfaction who travel to Demak. Tourists think that halal food in Demak is a natural thing and does not need to be precisely assessed. The results of this study support previous research conducted by Atieq (2020:119).

Third, halal-friendly facilities have a positive influence on tourist satisfaction who travel to Demak. Tourists also appreciate food restaurants displaying halal logos; the results of this study support previous research conducted by Saputro et al. (2018:278).

Fourth, halal-friendly services also do not affect tourist satisfaction who travel to Demak. Tourists think that halal services in Demak should indeed be given to tourists, considering that tourism in Demak is religious tourism, so that halal services do not need to be precisely assessed. The results of this study support previous research conducted by Kasdi \& Saifudin (2019:127).

Fifth, halal-friendly locals and other travellers have a positive influence on tourist satisfaction who travels to Demak. Tourists also perceive that, in general, local people and other tourists are kind and helpful to tourists; the results of this study support previous research conducted by Corte et al. (2015:45).

\section{CONCLUSION}

Based on the research results and discussion above, it can be concluded that the satisfaction of religious tourism tourists in Demak is influenced by halal-friendly accommodations, halal-friendly facilities, and halal-friendly locals and other travellers. On the other hand, halal foods and halal-friendly services do not affect the satisfaction of religious tourism tourists in Demak. In general, Demak religious tourism has succeeded in applying halal-friendly tourism. 


\section{REFERENCES}

Agusmal, \& Wardi, Y. (2020). Effects of Service Quality, Halal Tourism, Brand Image, Tourist Satisfaction and E-WOM on Muslim Tourist Loyalty in West Sumatra BT - Proceedings of the 5th Padang International Conference On Economics Education, Economics, Business and Management, Account. 592-598. https:// doi.org/https://doi.org/10.2991/aebmr.k.201126.066

Al-Ansi, A., \& Han, H. (2019). Role of halal-friendly destination performances, value, satisfaction, and trust in generating destination image and loyalty. Journal of Destination Marketing \& Management, 13, 51-60. https://doi.org/https://doi. org/10.1016/j.jdmm.2019.05.007

Al-Ansi, A., Olya, H. G. T., \& Han, H. (2019). Effect of general risk on trust, satisfaction, and recommendation intention for halal food.InternationalJournalofHospitality Management, 83, 210-219. https://doi.org/https://doi.org/10.1016/j. ijhm.2018.10.017

Alam, M. N., Nurzaman, M. S., \& Hasan, F. A. Al. (2019). The Influence of Sharia Compliance and Customer Experience on Satisfaction and Loyalty of Muslim Tourist who Visited Sharia Hotel BT - Proceedings of the 2018 International Conference on Islamic Economics and Business (ICONIES 2018). 57-63. https:// doi.org/https://doi.org/10.2991/iconies-18.2019.11

Amin, H., Abdul-Rahman, A. R., \& Razak, D. A. (2014). Theory of Islamic consumer behaviour: An empirical study of consumer behaviour of Islamic mortgage in Malaysia.JournalofIslamic Marketing, 5(2),273-301.https://doi.org/10.1108/ JIMA-06-2013-0042

Atieq, M. Q. (2020). Analysis Of Halal Labelling Towards Purchase Quantity And Consumer Satisfaction In Maomao (Thai Tea). Tasharruf: Journal Economics and Business of Islam, 5(1), 108-121.

Baniya, R., \& Thapa, P. (2017). Hotel Attributes Influencing International Tourists' Satisfaction and Loyalty. Journal of Tourism and Hospitality Education, 7(0 SEArticles), 44-61. https://doi.org/10.3126/jthe.v7i0.17689

BPS-Statistic of Demak. (2021). Demak in Figures 2021. In BPS-Statistics of Demak (Ed.), BPS-Statistics of Demak. BPS-Statistics of Demak. 
Corte, V. Della, Sciarelli, M., Cascella, C., \& Gaudio, G. Del. (2015). Customer Satisfaction in Tourist Destination: The Case of Tourism Offer in the City of Naples. Journal of Investment and Management, 4(1), 40-50. https://doi.org/10.11648/j. jim.s.2015040101.16

Dijkstra, T. K., \& Henseler, J. (2015). Consistent Partial Least Squares Path Modeling. MIS Q., 39(2), 297-316. https://doi.org/10.25300/MISQ/2015/39.2.02

Edgar, T. W., \& Manz, D. O. (2017). Chapter 4 - Exploratory Study (T. W. Edgar \& D. 0. B. T.-R. M. for C. S. Manz (eds.); pp. 95-130). Syngress. https://doi.org/https:// doi.org/10.1016/B978-0-12-805349-2.00004-2

Ghozali, I. (2021). Structural Equation Modeling Dengan Metode Alternatif Partial Least Squares (PLS) (5th ed.). Badan Penerbit Undip.

Han, H., Al-Ansi, A., Koseoglu, M. A., Lin, P. M. C., Park, J., Yu, J., \& Kim, W. (2019). Halal tourism: travel motivators and customer retention. Journal of Travel and Tourism Marketing, 36(9), 1012-1024. https://doi.org/10.1080/10548408.2 019.1683483

Handriana, T., Yulianti, P., \& Kurniawati, M. (2020). Exploration of pilgrimage tourism in Indonesia. Journal of Islamic Marketing, 11(3), 783-795. https:// doi.org/10.1108/JIMA-10-2018-0188

Hung, K., Yang, X., Wassler, P., Wang, D., Lin, P., \& Liu, Z. (2017). Contesting the Commercialization and Sanctity of Religious Tourism in the Shaolin Monastery, China. International Journal of Tourism Research, 19(2), 145-159. https://doi. org/https://doi.org/10.1002/jtr.2093

Jeaheng, Y., Al-Ansi, A., \& Han, H. (2020). Impacts of Halal-friendly services, facilities, and food and Beverages on Muslim travelers' perceptions of service quality attributes, perceived price, satisfaction, trust, and loyalty. Journal of Hospitality Marketing \& Management, 29(7), 787-811. https://doi.org/10.1080/193686 23.2020.1715317

Kasdi, A., \& Saifudin, S. (2019). Influence of Sharia Service Quality, Islamic Values, and Destination Image toward Loyalty Visitors' on Great Mosque of Demak. International Journal of Islamic Business and Economics (IJIBEC), 3(2), 117. https://doi.org/10.28918/ijibec.v3i2.1909

Kasdi, A., \& Saifudin, S. (2020). Resilience of Muslim Families in the Pandemic Era: Indonesian Millennial Muslim Community's Response Against COVID-19. 17(1), 81-94. 
Kemenparekraf RI. (2021). Potensi Pengembangan Wisata Halal di Indonesia. https://kemenparekraf.go.id/ragam-pariwisata/Potensi-PengembanganWisata-Halal-di-Indonesia-

Kim, B., Kim, S. (Sam), \& King, B. (2020). Religious tourism studies: evolution, progress, and future prospects. Tourism Recreation Research, 45(2), 185-203. https://doi.org/10.1080/02508281.2019.1664084

Mahrnasari, M., Mahfujur Rahman, M. D., Bangsawan, S., \& Mohd Shahril, A. (2020). Muslim friendly facilities of the Indonesian hotel industry: A smart tourism approach. Utopia y Praxis Latinoamericana, 25(Extra2), 190-201. https://doi. org/10.5281/zenodo.3809249

Mohammadi, A. M., \& Mohamed, B. (2011). Applying Consumer Behaviour Theory and Grand Models to Attendees Behaviour in Coference Industry. International Conference on Tourism \& Management Studies - Algarve, I(2006), 151-159.

Purwanto, A., Asbari, M., Santoso, P. B., Wijayanti, L. M., Hyun, C. C., \& Pramono, R. (2020). Halal Foods Purchase Intension among Indonesian Non-Muslim Consumers: An Exploratory Case Study Approach. International Journal of Science and Management Studies (IJSMS), April 2020, 15-27. https://doi. org/10.51386/25815946/ijsms-v3i2p103

Putit, L., Muda, M., Mahmood, A. N., Ahmad Taufek, N. Z., \& Wahib, N. (2016). Linking 'Halal' Friendly Hotel Attributes and Customer Satisfaction:The Islamic Tourism Sector. Journal of Emerging Economies and Islamic Research, 4(4), 4353. https://doi.org/10.24191/jeeir.v4i4.9102

Saputro, M. S. D., Wardi, Y., \& Abror, A. (2018). The Effect of Halal Tourism on Customer Satisfaction. 57(Piceeba), 275-282. https://doi.org/10.2991/ piceeba-18.2018.57

Sarstedt, M., Ringle, C. M., Smith, D., Reams, R., \& Hair, J. F. (2014). Partial least squares structural equation modeling (PLS-SEM): A useful tool for family business researchers. Journal of Family Business Strategy, 5(1), 105-115. https://doi. org/https://doi.org/10.1016/j.jfbs.2014.01.002 
halaman ini sengaja untuk dikosongkan 